\title{
PENGARUH MODEL PEMBELAJARAN KOOPERATIF DAN INTELEGENSI TERHADAP HASIL BELAJAR BIOLOGI
}

\author{
Hanita Khairina Lubis ${ }^{1}$ dan Abdul Hasan Saragih ${ }^{2}$ \\ SMA Al Azhar Medan ${ }^{1}$ dan Universitas Negeri Medan ${ }^{2}$ \\ Hanitakhairinalubis@yahoo.com ${ }^{1}$ dan ahasansaragih@gmail.com ${ }^{2}$
}

\begin{abstract}
Abstrak: Penelitian ini bertujuan: (1) Perbedaan peningkatan hasil belajar siswa yang menggunakan teknik jigsaw dan pembelajaran inside- outside-circle (2) Perbedaan antara hasil belajar Biologi siswa yang memiliki intelegensi tinggi dengan siswa yang memiliki intelengensi sedang. (3) Interaksi antara intelegensi siswa dengan teknik pembelajaran jigsaw dan pembelajaran inside-outside-circle terhadap hasil belajar Biologi siswa. Penelitian ini menggunakan metode eksperimental-semu dengan desain faktorial $2 \times 2$. Teknik analisis data pada penelitian ini adalah teknik statistik deskriptif untuk menyajikan data dan dilanjutkan dengan statistik inferensial dengan menggunakan ANAVA dua jalur dengan taraf signifikan $\alpha=0,05$ yang dilanjutkan dengan uji Scheffe. Hasil penelitian menunjukkan: (1) hasil belajar siswa yang menggunakan teknik jigsaw dan pembelajaran inside-outside-circle $F_{\text {hitung }}=8,885>F_{\text {tabel }}=4,03$; (2) hasil belajar siswa yang memiliki tingkat Intelegensi Tinggi, lebih tinggi dari hasil belajar siswa yang memiliki tingkat Intelegensi Sedang. Hal ini ditunjukkan dari hasil $F_{\text {hitung }}=52,048>$ $F_{\text {tabel }}=4,03$; dan (3) terdapat interaksi antara Teknik pembelajaran dengan Tingkat Intelegensi terhadap hasil belajar. Hal ini ditunjukkan dari hasil $F_{\text {hitung }}=20,334>F_{\text {tabel }}=4,03$.
\end{abstract}

Kata Kunci: model pembelajaran kooperatif, intelegensi, hasil belajar biologi

Abstract: This study aims: (1) The difference in improving student learning outcomes which uses techniques and learning jigsaw inside-outside-circle (2) The difference between the results of studying Biology students who have high intelligence with students who have a moderate intelengensi. (3) The interaction between the intelligence jigsaw students with learning techniques and learning inside-outside-circle to Biology student learning outcomes. This study uses a quasiexperimental method with $2 \times 2$ factorial design. Data analysis technique in this research is descriptive statistical techniques to present data and continued with inferential statistics using ANOVA two lanes with significance level $\alpha=0.05$, followed by Scheffe test. The results showed: (1) the results of student learning using jigsaw technique and learning inside-outside-circle of $F_{c}$ $=8.885>F_{t}=4.03$; (2) the learning outcomes of students who have high levels of High Intelligence, higher than student learning outcomes that have the intelligence level of Medium. It is shown from the results of $F_{c}=52.048>F_{t}=4.03$; and (3) there is interaction between learning technique with the intelligence level of the learning outcomes. It is shown from the results of $F_{c}=$ $20.334>F_{t}=4.03$.

Keywords: cooperative learning, intelligence, learning outcomes biology

\section{PENDAHULUAN}

Pembelajaran merupakan suatu kegiatan yang melibatkan seseorang dalam memperoleh pengetahuan, keterampilan dan nilai-nilai positif dengan memanfaatkan berbagai sumber untuk belajar. Pembelajaran dapat melibatkan dua pihak yaitu siswa sebagai pembelajar dan guru sebagai fasilitator. Hal terpenting dalam kegiatan pembelajaran adalah terjadinya proses belajar. Sesuatu dikatakan hasil belajar kalau memenuhi ciri-ciri sebagai berikut: (1) belajar sifatnya disadari, dalam hal ini siswa merasa dirinya sedang belajar, timbul dalam dirinya motivasi-motivasi untuk memiliki pengetahuan yang diharapkan sehingga tahapan-tahapan dalam belajar sampai pengetahuan ini dimiliki secara permanen betulbetul disadari sepenuhnya. (2) hasil belajar dengan adanya proses, dalam hal ini pengetahuan ini diperoleh tidak secara spontanitas, instan, namun bertahap. (3) belajar membutuhkan interaksi, khususnya interaksi yang sifatnya manusiawi. (Susilana, 2007)

Kaitan antara belajar membutuhkan interaksi, hal ini menunjukkan bahwa proses pembelajaran merupakan proses komunikasi, 
artinya di dalamnya terjadi proses penyampaian pesan dari seseorang (sumber pesan) kepada seseorang atau sekelompok orang (penerima pesan) (Kemp,1975). Faktor yang dapat mempengaruhi efektivitas sebuah komunikasi, baik faktor yang terjadi pada pengirim maupun penerima pesan menurut Susilana (2007) adalah: (1) Kemampuan berkomunikasi penyampaian pesan seperti kemampuan bertutur dan berbahasa dan kemampuan menulis. (2) Sikap dan pandangan penyampaian pesan dan kepada penerima dan sebaliknya. (3) Tingkat pengetahuan baik penerima maupun penyampain pesan. Sumber pesan yang kurang memahami informasi yang lebih dicapai akan mempengaruhi gaya dan sikap dalam penyampaian pesan. Sebaliknya, penerima pesan yang kurang mempunyai pengetahuan dan pengalaman terhadap informasi yang disampaikan tidak akan mampu mencerna informasi dengan baik. (4) Latar belakang sosial budaya dan ekonomi penyampaian pesan serta penerima pesan. Ketanggapan penerimaan pesan dalam merespon informasi tergantung dari siapa dan oleh siapa pesan itu disampaikan.

Proses perancangan pembelajaran selalu diawali dengan perumusan tujuan instruksional khusus sebagai pengembangan tujuan instruksional umum. Perumusan indikator selalu merujuk pada kompetensi dasar dan kompetensi dasar selalu merujuk pada standar kompetensi. Guru menyediakan fasilitas belajar bagi peserta didik.

Biologi merupakan wahana untuk meningkatkan pengetahuan, keterampilan, sikap dan nilai. Belajar biologi merupakan suatu aktivitas yang dilakukan secara sengaja oleh pembelajar atau siswa dalam usaha memahami fakta-fakta, konsep-konsep, aturan-aturan, hukum-hukum, prinsip-prinsip dan teori-teori dan kemudian menerapkan ke dalam situasi lain seperti: hafalan-hafalan, pemahaman, perhitungan-perhitungan, praktikum, dan penarikan kesimpulan.

Pendidikan biologi menekankan pada pemberian pengalaman secara langsung, karena itu siswa perlu dibantu untuk mengembangkan sejumlah keterampilan proses supaya mereka mampu menjelajahi dan memahami alam sekitar. Keterampilan proses ini meliputi keterampilan mengamati dengan seluruh indera, mengajukan hipotesis, menggunakan alat dan bahan secara benar dengan selalu mempertimbangkan keselamatan kerja, mengajukan pertanyaan, menggolongkan, menafsirkan data dan juga mengkomunikasikan hasil temuan secara beragam, menggali dan memilih informasi faktual yang relevan untuk menguji gagasan dan memecahkan masalah sehari-hari. Disamping itu, kemungkinan untuk mengembangkan teknologi relevan dari konsepkonsep biologi yang dipelajari sangat dianjurkan dalam kegiatan pembelajaran. Dengan demikian, siswa dapat merasakan manfaat pembelajaran biologi tersebut bagi diri sendiri serta masyarakat.

Tujuan mata pelajaran IPA biologi adalah agar peserta didik memiliki kemampuan sebagai berikut: (1) Membentuk sikap positif terhadap biologi dengan menyadari keteraturan dan keindahan alam serta mengagungkan kebesaran Tuhan Yang Maha Esa. (2) Memupuk sikap ilmiah yaitu jujur, objektif, terbuka, ulet, kritis dan dapat bekerjasama dengan orang lain. (3) Mengembangkan pengalaman untuk dapat mengajukan dan menguji hipotesis melalui percobaan, serta mengkomunikasikan hasil percobaan secara lisan dan tertulis. (4) Mengembangkan kemampuan berpikir analitis, induktif, dan deduktif dengan menggunakan konsep dan prinsip biologi. (5) Mengembangkan penguasaan konsep dan prinsip biologi dan saling keterkaitannya dengan IPA lainnya serta mengembangkan pengetahuan, keterampilan dan sikap percaya diri. (6) Menerapkan konsep dan prinsip biologi untuk menghasilkan karya teknologi sederhana yang berkaitan dengan kebutuhan manusia. (7) Meningkatkan kesadaran dan berperan serta dalam menjaga kelestarian lingkungan. (Anonim, 2006)

Mata pelajaran biologi di SMA/MA merupakan kelanjutan IPA di SMP/MTs yang menekankan pada fenomena alam dan penerapannya yang meliputi aspek-aspek sebagai berikut: (1) Hakikat biologi, keanekaragaman hayati dan pengelompokan makhluk hidup, hubungan antar komponen ekosistem, perubahan materi dan energi, peranan manusia dalam keseimbangan ekosistem. (2) Organisasi seluler, struktur jaringan, struktur dan fungsi organ tumbuhan, hewan dan manusia serta penerapannya dalam konteks sains, lingkungan, teknologi dan masyarakat. (3) Proses yang terjadi pada tumbuhan, proses metabolisme, hereditas, evolusi, bioteknologi dan implikasinya pada sains, lingkungan, teknologi, dan masyarakat.

Dalam proses pembelajaran biologi yang berlangsung di SMA saat ini menggunakan sistem penyampaian yang monoton, yaitu sistem yang bertumpu pada aktivitas guru. Pada 
umumnya guru cenderung menggunakan metode ceramah dalam mengajar karena mudah dilakukan dan cepat. Bertumpunya proses belajar mengajar pada guru menimbulkan kurang tumbuh berkembangnya sikap pembelajaran pada anak, sebab anak akan cenderung menganggap dirinya tergantung pada guru dan sekolah demi belajar. Tanpa guru dan sekolah siswa tidak dapat belajar secara teratur. Sikap ini bahkan dapat tumbuh dalam diri orang tuanya, sehingga sekolah dan guru dianggap sebagai satu-satunya pihak yang bertanggung jawab atas keberhasilan anak dalam belajar.

Salah satu upaya untuk mengatasi masalah peningkatan mutu dalam pendidikan sains atau biologi tersebut adalah dengan menerapkan pembelajaran yang menitik beratkan pada keterampilan-keterampilan tertentu seperti keterampilan dalam menyelesaikan masalah, keterampilan dalam mengamati obyek, keterampilan dalam mengambil keputusan, keterampilan dalam menganalisis data, berfikir secara logis, sistematis serta keterampilan dalam mengajukan pertanyaan. Sehingga pembelajaran akan lebih menitik beratkan kepada siswa dan siswa aktif dalam mengikuti kegiatan belajar mengajar. Menurut pandangan konstruktivisme belajar berarti membentuk makna. Makna diciptakan oleh siswa dari apa yang mereka lihat, dengar, rasakan dan alami. Bagi kaum konstruktivisme mengajar bukanlah kegiatan memindahkan pengetahuan dari guru ke murid, melainkan suatu kegiatan yang memungkinkan siswa membangun sendiri pengetahuannya.

Sesuai dengan faham konstruktivisme, pengetahuan itu dibangun sendiri dalam pikiran siswa, pengetahuan tersebut dapat diperoleh dari pengalaman fisik dan juga dari orang lain melalui transmisi sosial. Hal ini sesuai dengan pendapat Lorbach dan Tobin yang menyatakan bahwa pengetahuan tidak dapat ditransfer begitu saja dari otak seorang guru kepada siswa, siswa sendiri yang harus memaknai apa yang telah diajarkan dengan menyesuaikan terhadap pemahamannya, dan salah satu penerapan konstruktivisme dalam pembelajaran di sekolah adalah pembelajaran kooperatif (Cooperative Learning).

$$
\text { Kegiatan pembelajaran }
$$

seperti

Cooperative Learning turut menambah unsurunsur interaksi sosial pada pembelajaran IPA. Menurut Slavin dalam Hernani (2004), pembelajaran kooperatif merupakan sekelompok kecil siswa yang bekerja sama untuk belajar dan bertanggung jawab pada kelompoknya. Menurut Killen, Cooperative Learning merupakan suatu teknik instruksional dan filosofi pembelajaran yang berusaha meningkatkan kemampuan siswa untuk bekerjasama dalam kelompok kecil, guna memaksimalkan kemampuan belajarnya, dan belajar dari temannya serta memimpin dirinya (Suasti,2003). Di dalam pembelajaran kooperatif, siswa belajar bersama dalam kelompok-kelompok kecil dan saling membantu satu sama lain. Hal ini bermanfaat untuk melatih siswa menerima pendapat orang lain dan berkerja dengan teman yang berbeda latar belakangnya, membantu memudahkan menerima materi pelajaran, meningkatkan kemampuan berfikir dalam memecahkan masalah. Karena dengan adanya komunikasi antara anggota-anggota kelompok dalam menyampaikan pengetahuan serta pengalamannya sehingga dapat menambahkan pengetahuan dan meningkatkan hasil belajar serta hubungan sosial setiap anggota kelompok.

Dari daftar kumpulan nilai di atas dapat diketahui hasil belajar yang diperoleh siswa SMA Al Azhar Medan rendah. Rendahnya pencapaian hasil belajar ini dipengaruhi oleh faktor internal dan faktor eksternal. Salah satu faktor internal adalah intelegensi siswa. Selain teknik dan hasil belajar, maka perlu juga diperhatikan intelegensi siswa. Intelegensi adalah suatu kemampuan dimana seseorang dapat menyelesaikan masalah dengan cepat dan tepat. Dalam dunia pendidikan intelegensi merupakan salah satu masalah pokok. Semakin tinggi intelegensi siswa maka semakin tinggi pula hasil belajarnya dan sebaliknya semakin rendah intelegensi siswa maka semakin rendah pula hasil belajarnya. Faktor eksternal terkait dengan teknik pembelajaran yang disajikan guru. Kemungkinan kurangnya pemahaman siswa dalam proses pembelajaran biologi dikarenkan guru memberikan materi secara monoton. Untuk meningkatkan pemahaman siswa dalam proses pembelajaran maka diperlukan teknik-teknik dalam proses belajar di kelas sehingga dapat memberikan alternatif pendekatan atau metode yang memungkinkan untuk diterapkan dalam proses pembelajaran biologi dengan kekhususan pokok bahasan pada pelajaran biologi sedangkan hasil belajar siswa diukur dengan memberikan tes kepada siswa.

Teknik yang digunakan dalam pembelajaran biologi yang akan digunakan 
adalah teknik jigsaw dan teknik inside-outside circle yang akan dibandingkan adalah hasil belajarnya. Pembelajaran kooperatif teknik jigsaw adalah suatu teknik pembelajaran yang didasarkan pada bentuk struktur multi fungsi kelompok belajar yang dapat digunakan pada semua pokok bahasan dan semua tingkatan untuk mengembangkan keahlian dan keterampilan setiap anggota kelompok, teknik jigsaw terdiri dari dua bentuk diskusi yaitu diskusi kelompok ahli dan diskusi kelompok asal sehingga dalam teknik pembelajaran ini tergantung pada dan belajar dari orang lain dan menciptakan saling ketergantungan bagi tiap anggota kelompok. Teknik pembelajaran Inside- outside- circle (lingkaran kecil-lingkaran besar) merupakan teknik pembelajaran dimana siswa dapat berinteraksi dengan siswa lainnya tanpa diliputi rasa takut salah pada saat mengungkapkan pendapatnya. Teknik pembelajaran ini menuntut siswa saling membagi informasi pada saat yang bersamaan, dengan pasangan yang berbeda dengan singkat dan teratur. Dari kedua teknik jigsaw dan inside-outside circle maka akan dibandingkan dengan hasil belajar.

Berdasarkan kondisi di atas maka penulis melakukan penelitian dengan judul " Pengaruh Model Pembelajaran Kooperatif dan Intelegensi Terhadap Hasil Belajar Biologi Siswa Kelas XI SMA Al Azhar Medan Tahun Ajaran 20102011".

Belajar merupakan suatu proses yang tidak dapat dilihat dengan nyata, proses itu terjadi di dalam diri seseorang yang sedang mengalami belajar. Menurut Good dan Brophy bukan tingkah laku yang nampak, tetapi terutama adalah prosesnya yang terjadi secara internal di dalam diri individu dalam usahanya memperoleh hubungan-hubungan baru (Purwanto, 2000). Hubungan-hubungan baru itu dapat berupa: antara perangsangperangsang, antara reaksi-reaksi, atau antara perangsang dan reaksi. Faktor-faktor penting yang sangat erat hubungannya dengan proses belajar ialah: kematangan, penyesuaian diri/adaptasi, menghafal/mengingat, pengertian, berpikir dan latihan (Purwanto, 2000).

Dalam belajar dihasilkan berbagai macam tingkah laku yang berlainan seperti pengetahuan, sikap, keterampilan, kemampuan, informasi dan nilai. Berbagai macam tingkah laku yang berlainan inilah yang disebut kapabilitas sebagai hasil belajar (Ibrahim,2001).

Perubahan dalam menunjukkan kinerja (perilaku) berarti belajar menentukan semua keterampilan, pengetahuan dan sikap yang juga didapat oleh setiap siswa dari proses belajarnya. Secara umum Reigeluth mengatakan bahwa hasil pembelajaran secara umum dapat dikategorisasi menjadi tiga (3) indikator, yaitu: (1) efektivitas pembelajaran, yang biasanya di ukur dari tingkat keberhasilan (prestasi) siswa dari berbagai sudut: (2) efisiensi pembelajaran,yang biasanya diukur dari waktu belajar dan atau biaya pembelajaran, (3) daya tarik pembelajaran yang selalu diukur dari tendensi siswa ingin belajar secara terus menerus. Secara spesifik, hasil belajar adalah suatu kinerja (performance) yang diindikasikan sebagai suatu kapabilitas (kemampuan) yang telah diperoleh. Tingkat keberhasilan siswa dalam mempelajari materi pelajaran biologi di sekolah dapat diukur dalam bentuk skor yang diperoleh dari hasil tes, ini nantinya dapat digunakan untuk menilai hasil proses belajar mengajar dalam jangka waktu tertentu. Pemberian tes dilakukan dengan mengacu pada indikator dan keterampilan berpikir tertentu.

Terdapat empat kelompok besar dari model pembelajaran yang diungkapkan dalam Joyce (2009) yaitu: (1) information processing models yang berorientasi kepada pengembangan kemampuan siswa dalam mengolah dan menguasai informasi yang diterima dengan menitikberatkan aspek intelektual akademis, (2) personal models yang berorientasi kepada pengembangan pribadi siswa baik sebagai individu maupun dalam hubungannya dengan lingkungan dan juga menekankan pada aspek kehidupan emosional, (3) social interaction models yang berorientasi kepada pengembangan kemampuan siswa dalam bekerjasama dengan orang lain, berperan aktif dalam proses demokrasi dan bekerja dengan produktif di dalam masyarakat yang menitikberatkan aspek kehidupan sosial dan (4) behavioral models yang berorientasi kepada pengembangan kemampuan menguasai fakta, konsep, keterampilan, dan kemampuan mengurangi kecemasan serta meningkatkan ketenangan dengan menitikberatkan aspek perbuatan prilaku yang dapat diamati.

Salah satu bentuk pembelajaran yang sesuai dengan falsafah dari pendekatan konstruktivis adalah model pembelajaran kooperatif. Model pembelajaran kooperatif adalah pembelajaran aktif yang menekankan aktivitas siswa bersama-sama secara berkelompok dan tidak individual. Siswa secara berkelompok mengembangkan kecakapan hidupnya, seperti menemukan dan memecahkan 
masalah, mengambil keputusan, berpikir logis, berkomunikasi efektif, dan bekerja sama (Hakim, 2008).

Menurut Lie, A. (2002) pembelajaran kooperatif adalah sistem pengajaran yang memberi kesempatan kepada siswa untuk bekerjasama dengan sesamanya dalam tugastugas yang terstruktur. Pembelajaran kooperatif mencakup suatu kelompok kecil siswa yang bekerjasama sebagai sebuah tim untuk mencapai tujuan bersama lainnya. Dalam kegiatan pembelajaran kooperatif ini siswa menjadi lebih aktif dan guru berperan untuk mengelola dan mengawasi aktivitas kelompok siswa.

Model pembelajaran kooperatif dapat dilakukan dengan mengelompokkan siswa menjadi kelompok-kelompok kecil. Namun, tidak semua pembelajaran yang dilakukan secara kelompok merupakan pembelajaran kooperatif. Pengelolaan kelompok siswa dalam pembelajaran kooperatif dilakukan secara heterogenitas (kemacamragaman). Kelompok heterogenitas bisa dibentuk dengan memperhatikan keanekaragaman gender, latar belakang agama sosio-ekonomi dan etnik, serta kemampuan akademis. Dalam hal kemampuan akademis, kelompok pembelajaran kooperatif biasanya terdiri dari satu orang berkemampuan akademis tinggi, dua orang berkemampuan akademis sedang, dan seorang lagi berkemampuan akademis kurang. Kendala yang sering dihadapi oleh guru dalam pengelompokan seperti ini adalah adanya keberatan dari siswa yang berkemampuan akademis tinggi yang dikelompokkan dengan siswa yang berkemampuan akademis rendah.

Jigsaw adalah suatu struktur multifungsi struktur kerjasama belajar. Jigsaw dapat digunakan dalam beberapa hal untuk mencapai berbagai tujuan tetapi terutama digunakan untuk persentasi dan mendapatkan materi baru, struktur ini menciptakan saling ketergantungan. Berdasarkan paparan tersebut, dapat disimpulkan bahwa pembelajaran kooperatif teknik jigsaw adalah suatu metode pembelajaran yang didasarkan pada bentuk struktur multifungsi kelompok belajar yang dapat digunakan pada semua pokok bahasan dan semua tingkatan untuk mengembangkan keahlian dan keterampilan setiap anggota kelompok, teknik jigsaw terdiri dari dua bentuk diskusi yaitu diskusi kelompok ahli dan diskusi kelompok asal sehingga dalam metode pembelajaran ini tergantung pada dan belajar dari orang lain dan menciptakan saling ketergantungan bagi tiap anggota kelompok.

Tabel 1. Tahapan-tahapan Kegiatan Pembelajaran Kooperatif Teknik Jigsaw

\begin{tabular}{|l|l|l|}
\hline Tahapan & Kegiatan & Keterangan \\
\hline Pertama & $\begin{array}{l}\text { Membentuk } \\
\text { kelompok besar } \\
\text { yang heterogen }\end{array}$ & $\begin{array}{l}\text { Guru membagi siswa dalam kelompok yang berjumlah 5-6 } \\
\text { orang disebut kelompok asal }\end{array}$ \\
\hline Kedua & $\begin{array}{l}\text { Memilih pemimpin } \\
\text { kelompok }\end{array}$ & $\begin{array}{l}\text { Menugaskan satu orang siswa dari masing-masing } \\
\text { kelompok sebagai pemimpin, umumnya siswa yang dewasa } \\
\text { dalam kelompok itu. }\end{array}$ \\
\hline Ketiga & $\begin{array}{l}\text { Membagika materi } \\
\text { membentuk ahli }\end{array}$ & $\begin{array}{l}\text { Membagi tugas materi yang berbeda pada tiap siswa dalam tiap } \\
\text { kelompok }\end{array}$ \\
\hline Keempat & $\begin{array}{l}\text { Mempelajari satu } \\
\text { segmen untuk tiap } \\
\text { siswa }\end{array}$ & $\begin{array}{l}\text { Menugaskan tiap siswa untuk mempelajari satu segmen dan } \\
\text { untuk menguasai segmen mereka sendiri }\end{array}$ \\
\hline Segmen setiap & $\begin{array}{l}\text { Memberi kesempatan kepada para siswa itu untuk } \\
\text { membaca secepatnya segmen mereka sedikitnya dua kali agar } \\
\text { mereka terbiasa dan tidak ada waktu untuk menghafal. }\end{array}$ \\
\hline Keenam & $\begin{array}{l}\text { Membentuk } \\
\text { kelompok ahli }\end{array}$ & $\begin{array}{l}\text { Guru membentuk kelompok ahli dengan satu orang dari } \\
\text { masing-masing kelompok jigsaw bergabung dengan siswa lain } \\
\text { yang memiliki segmen yang sama untuk mendiskusikan poin- } \\
\text { poin yang utama dari segmen mereka dan berlatih } \\
\text { presentasi kepada kelompok jigsaw mereka }\end{array}$ \\
\hline Ketujuh & $\begin{array}{l}\text { Kembali } \\
\text { kekelompok } \\
\text { jigsaw }\end{array}$ & $\begin{array}{l}\text { Siswa berdiskusi dalam kelompok berdasarkan kesamaan } \\
\text { materi yang diberikan pada masing-masing siswa }\end{array}$ \\
\hline
\end{tabular}




\begin{tabular}{|l|l|l|}
\hline Delapan & $\begin{array}{l}\text { Diskusi kelompok } \\
\text { besar/asal }\end{array}$ & $\begin{array}{l}\text { Siswa berdiskusi kembali dalam kelompok asalnya masing- } \\
\text { masing berdasarkan ketentuan guru }\end{array}$ \\
\hline Sembilan & $\begin{array}{l}\text { Pemberian kuis } \\
\text { individu semua } \\
\text { materi }\end{array}$ & $\begin{array}{l}\text { Guru melakukan penilaian untuk mengukur kemampuan dan } \\
\text { hasil belajar siswa mengenai } \\
\text { seluruh pembahasan }\end{array}$ \\
\hline Sepuluh & $\begin{array}{l}\text { Pemberian } \\
\text { penghargaan }\end{array}$ & $\begin{array}{l}\text { Memberikan penghargaan kepada kelompok dan siswa } \\
\text { berprestasi }\end{array}$ \\
\hline
\end{tabular}

Teknik mengajar lingkaran besar dan lingkaran kecil (inside - outside - circle) dikembangkan oleh Spencer Kagan untuk memberikan kesempatan pada siswa agar saling berbagi informasi pada saat yang bersamaan. Pendekatan ini bisa digunakan dalam beberapa mata pelajaran, seperti ilmu pengetahuan alam, social, agama, matematika dan bahasa. Bahan pelajaran yang paling cocok digunakan dengan teknik ini adalah bahan yang membutuhkan pertukaran pikiran dan informasi antar siswa.

Salah satu keunggulan teknik ini adalah adanya struktur yang jelas yang memungkinkan siswa untuk berbagi dengan pasangan yang berbeda dengan singkat dan teratur. Selain itu siswa bekerja dengan sesama siswa dalam suasana gotong royong dan mempunyai banyak kesempatan untuk mengolah informasi dan meningkatkan keterampilan berkomunikasi.

Tabel 2. Skema kegiatan pembelajaran teknik inside-outside circle

\begin{tabular}{|c|c|c|}
\hline KEGIATAN GURU & LANGKAH & KEGIATAN SISWA \\
\hline 1. Siapkan materi & Kajian materi & Duduk dalam kelas \\
\hline 2. Bentuk kelompok & $\begin{array}{l}\text { Kelompok lingkaran besar } \\
\text { dan kelompok lingkaran } \\
\text { kecil }\end{array}$ & $\begin{array}{l}\text { Membentuk lingkaran luar dan } \\
\text { dalam sehingga mendapatkan } \\
\text { berpasangan (pasangan awal). }\end{array}$ \\
\hline $\begin{array}{l}\text { 3. Memberikan materi setiap } \\
\text { pasangan }\end{array}$ & $\begin{array}{l}\text { Pasangan membahas } \\
\text { materi yang diberikan }\end{array}$ & Diskusi \\
\hline $\begin{array}{l}\text { 1. Memberikan arahan } \\
\text { kepada kelompok } \\
\text { lingkaran besar untuk } \\
\text { berputar searah jarum jam }\end{array}$ & Pasangan berdiskusi. & $\begin{array}{l}\text { Berbagi informasi antar pasangan } \\
\text { yang baru. Setiap pasangan wajib } \\
\text { memberikan informasi berdasarkan } \\
\text { hasil diskusi dengan pasangan awal }\end{array}$ \\
\hline $\begin{array}{l}\text { 2. Memberikan ulasan dan } \\
\text { evaluasi }\end{array}$ & $\begin{array}{l}\text { Kelompok besar } \\
\text { melakukan diskusi untuk } \\
\text { membuat kesimpulan }\end{array}$ & Membuat kesimpulan \\
\hline $\begin{array}{l}\text { 3. Melakukan tanya jawab } \\
\text { tentang ulasan dari tiap } \\
\text { lingkaran }\end{array}$ & $\begin{array}{l}\text { Siswa menceritakan ulang } \\
\text { hal yang telah dibicarakan } \\
\text { sebelumnya }\end{array}$ & Siswa berinteraksi dengan guru \\
\hline 8. Berikan kuis & Kuis & Ikuti kuis \\
\hline $\begin{array}{l}\text { 9. Hitung skor kuis/ berikan } \\
\text { penghargaan }\end{array}$ & Penghargaan & Menerima penghargaan \\
\hline
\end{tabular}

Intelegensi atau kecerdasan merupakan suatu kemampuan tertinggi dari jiwa makhluk hidup yang hanya dimiliki oleh manusia. Intelegensi ini diperoleh manusia dan sejak itulah potensi intelegensi ini mulai berfungsi mempengaruhi tempo dan kualitas perkembangan individu, dan manakala sudah berkembang, maka fungsinya akan semakin berarti lagi bagi manusia yaitu akan mempengaruhi kualitas penyesuaian dirinya dengan lingkungannya. Menurut Wahab dkk (2004) menjelaskan intelegensi adalah kemampuan yang dibawa sejak lahir yang memungkinkan sesorang berbuat sesuatu dengan cara tertentu. Atau kemampuan yang bersifat umum tersebut meliputi tersebut meliputi berbagai jenis psikis seperti abstrak, berpikir mekanis, matematis, memahami, mengingat bahasa dan sebagainya. Sedangkan Anastasi (1997) mengemukakan intelegensi adalah kemampuan untuk mengetahui problem serta kondisi baru. Kemampuan berpikir abstrak, kemampuan bekerja, kemampuan menguasai tingkah laku instrinsi, serta kemampuan menerima hubungan yang kompleks. Definisi intelegensi menurut Reber 
(1985) adalah kemampuan psikofisik untuk mereaksi rangsangan atau menyesuaikan diri dengan lingkungan dengan cara yang tepat. Sedangkan intelegensi menurut David Wechsler dalam Azwar, 2004 adalah kumpulan atau totalitas kemampuan seseorang untuk bertindak dengan tujuan tertentu, berfikir secara rasional serta menghadapi lingkungannya dengan efektif.

Berdasarkan teori Cattell dan Piaget bahwa terdapat pengaruh pengalaman, edukasi dan adaptasi dalam terbentuknya intelegensi seseorang. Intelegensi dapat diartikan juga sebagai kemampuan seseorang dalam menanggapi dan memahami peristiwa yang terjadi dalam kehidupannya. Baik dalam proses edukasi ataupun adaptasi yang terjadi selama manusia bersosialisasi dengan masyarakat dan lingkungan.

Kemampuan seseorang dalam memberikan tanggapan dan pemahaman selama proses edukasi dan adaptasi berbeda-beda. Sebagian orang dapat memberikan tanggapan dan pemahaman dalam waktu yang cenderung singkat, adapula yang membutuhkan waktu yang lebih lama untuk dapat memberikan tanggapan dan pemahaman dalam proses edukasi dan adaptasi yang sama. Kemampuan seseorang tersebut berhubungan dengan tingkat intelegensinya. Seseorang yang membutuhkan waktu yang lebih cepat diasumsikan memiliki tingkat intelegensi yang lebih tinggi dari pada orang yang membutuhkan waktu yang lebih lama dalam memberikan respon dan tanggapan. Intelegensi yang ditunjukkan berdasarkan kemampuan seseorang dalam memberikan tanggapan sesuai teori Cattell tentang intelegensi fluid (gf), yang yang menuntut kemampuan adaptasi pada situasi-situasi baru.

Rumusan masalah sebagai berikut: (1) Apakah hasil belajar siswa yang diajarkan dengan menggunakan teknik Jigsaw lebih tinggi dari pada hasil belajar siswa yang diajarkan dengan menggunakan teknik inside- outsidecircle?; (2) Apakah siswa yang memiliki intelegensi tinggi memperoleh hasil belajar Biologi yang lebih tinggi dari pada siswa yang memiliki intelegensi sedang?; dan (3) Apakah terdapat interaksi antara intelegensi siswa dengan model pembelajaran kooperatif dengan teknik inside- outside-circle atau dengan teknik jigsaw?

\section{METODE}

Penelitian ini dilakukan di SMA Al Azhar Medan. Jalan Pintu Air IV Medan Johor. Waktu pelaksanaan penelitian mulai FebruariMei 2011. Penetapan perlakuan disesuaikan dengan jadwal yang berlaku dikalender pendidikan SMA Al Azhar Medan.

Populasi adalah keseluruhan subjek penelitian. Populasi dalam penelitian ini adalah seluruh siswa SMA Al Azhar Medan kelas XI terdiri dari 4 kelas dengan jumlah siswa 120 orang. Sampel dalam peneletian ini digunakan dengan menggunakan cluster random dengan ketentuan bahwa setiap kelas dalam populasi memiliki karakteristik yang sama yaitu tidak memiliki kelas unggulan. Dari empat kelas yang diambil dua kelas yaitu kelas XI IA B yang berjumlah 28 orang dan XI IA D yang berjumlah 28 orang. Selanjutnya siswa yang dijadikan sampel dari kedua kelas adalah siswa yang memiliki intelegensi tinggi dan siswa yang memiliki intelegensi sedang.

Metode dalam penelitian ini adalah metode quasy eksperimen, dengan membagi kelompok penelitian menjadi dua kelompok eksperimen, yaitu kelompok pertama adalah kelompok eksperimen yang belajar dengan model pembelajaran kooperatif teknik jigsaw dan kelompok kedua adalah kelompok eksperimen yang belajar dengan model pembelajaran kooperatif teknik inside-outside circle. Rancangan penelitian yang digunakan adalah rancangan faktorial $2 \times 2$ seperti terlihat pada tabel 3. berikut.

Tabel 3. Desain Eksperimental Faktorial 2x2

\begin{tabular}{|l|l|l|}
\hline \multirow{2}{*}{$\begin{array}{l}\text { Intelegensi } \\
(\mathrm{B})\end{array}$} & \multicolumn{2}{|l|}{$\begin{array}{l}\text { Teknik Pembelajaran } \\
(\mathrm{A})\end{array}$} \\
\cline { 2 - 3 } & $\begin{array}{l}\text { Jigsaw } \\
\left(\mathrm{A}_{1}\right)\end{array}$ & IOC $\left(\mathrm{A}_{2}\right)$ \\
\hline Tinggi $\left(\mathrm{B}_{1}\right)$ & $\mathrm{A}_{1} \mathrm{~B}_{1}$ & $\mathrm{~A}_{2} \mathrm{~B}_{1}$ \\
\hline Sedang $\left(\mathrm{B}_{2}\right)$ & $\mathrm{A}_{1} \mathrm{~B}_{2}$ & $\mathrm{~A}_{2} \mathrm{~B}_{2}$ \\
\hline
\end{tabular}

Keterangan:

$\mathrm{A}_{1} \mathrm{~B}_{1}=$ Hasil belajar siswa yang diajar dengan teknik pembelajaran jigsaw dan memiliki intelegensi tinggi.

$A_{1} B_{2}=$ Hasil belajar siswa yang diajar dengan teknik pembelajaran jigsaw dan memiliki kemampuan berpikir logis sedang.

$\mathrm{A}_{2} \mathrm{~B}_{1}=$ Hasil belajar siswa yang diajar dengan teknik IOC dan memiliki intelegensi tinggi. 
$\mathrm{A}_{2} \mathrm{~B}_{2}=$ Hasil belajar siswa yang diajar dengan teknik IOC dan memiliki intelegensi sedang.

Teknik pengumpulan data yang digunakan adalah tes dan instrumen pengumpulan data yaitu tes intelegensi siswa dan tes hasil belajar biologi siswa. Untuk mendapatkan data hasil belajar dalam penelitian ini dilakukan tes setelah proses pembelajaran sesuai materi yang diperlakukan. Jenis tesnya adalah tes tertulis bentuk pilihan ganda dengan cara menjumlahkan skor masing-masing jawaban yang benar. Sementara instrumen yang digunakan adalah tes, angket dan catatan lapangan. Teknik analisis yang digunakan adalah teknik statistic deskriptif inferensial. Teknik analisis deskriptif digunakan untuk mendeskripsikan data penelitian dengan daftar distribusi frekuensi dan membuat histrogram. Dari data tersebut selanjutnya akan dihitung mean, median, modus dan standar deviasi dan varians. Teknik statistik inferensial digunakan untuk menguji hipotesis penelitian dengan menggunakan teknik analisis varians (ANAVA) dua jalur, setelah dilakukan uji persyaratan analisis data

\section{HASIL DAN PEMBAHASAN \\ Hasil}

Hipotesis pada penelitian ini diuji dengan menggunakan analisis varians (ANAVA) dua jalur dengan faktorial $2 \times 2$. Rangkuman data hasil perhitungan analisis deskriptif dapat dilihat pada tabel 4 . berikut.

Tabel 4. Rangkuman Data Hasil Perhitungan Analisis Deskriptif

\begin{tabular}{|c|c|c|c|}
\hline \multirow{2}{*}{ Intelijensi } & \multicolumn{2}{|c|}{ Teknik Pembelajaran } & \multirow{2}{*}{ JUMLAH } \\
\hline & Jigsaw & IOC & \\
\hline $\mathrm{N}=$ & 14 & 13 & $\mathrm{~N}=27$ \\
\hline$\sum \chi=$ & 854 & 734 & $\sum \chi=1588$ \\
\hline$\sum \chi^{2}=$ & 52156 & 41466 & $\begin{array}{c}\sum \chi^{2} \\
=\end{array} 93622$ \\
\hline$\chi^{-2}=$ & 61.000 & 56.462 & $\chi^{-}=58.815$ \\
\hline $\mathrm{S}=$ & 2.184 & 1.391 & $S=2.936$ \\
\hline$S^{2}=$ & 4.769 & 1.936 & $S^{2}=8.618$ \\
\hline $\mathrm{N}=$ & 14 & 15 & $\mathrm{~N}=29$ \\
\hline$\sum \chi=$ & 755 & 825 & $\sum \chi=1580$ \\
\hline$\sum \chi^{2}=$ & 40817 & 45451 & $\begin{array}{c}\sum \chi^{2} \\
=\end{array} 86268$ \\
\hline$\chi^{-2}=$ & 53.929 & 55.000 & $\chi^{-}=54.483$ \\
\hline $\mathrm{S}=$ & 2.496 & 1.946 & $S=2.572$ \\
\hline $\mathrm{S}^{2}=$ & 6.231 & 3.786 & $S^{2}=6.616$ \\
\hline $\mathrm{N}=$ & 28 & 28 & $\mathrm{~N}=56$ \\
\hline$\sum \chi=$ & 1609 & 1559 & $\sum \chi=3168$ \\
\hline$\sum \gamma^{2}=$ & 92973 & 86917 & $\sum \chi^{2} \quad 179890$ \\
\hline$\chi^{2 x}=$ & 57.464 & 55.679 & $\chi^{--}=56.571$ \\
\hline $\mathrm{S}=$ & 4.359 & 2.056 & $\mathrm{~S}=3.495$ \\
\hline$S^{2}=$ & 18.999 & 4.226 & $S^{2}=12.213$ \\
\hline
\end{tabular}

Dari hasil perhitungan analisis varians dua jalur diperoleh data yang dirangkum seperti pada tabel 5 berikut.

Tabel 5. Rangkuman Hasil ANAVA Faktorial 2 x 2

\begin{tabular}{|c|c|c|c|c|c|}
\hline Sumber Varians & dk & JK & RJK & $\mathbf{F}_{\text {hitung }}$ & $\begin{array}{c}\mathbf{F}_{\text {tabel(1:52) }} \\
\boldsymbol{a}=\mathbf{0 , 0 5}\end{array}$ \\
\hline Teknik Pembelajaran (Antar Kolom) & 1 & 44,643 & 44,643 & 8,855 & 4,03 \\
\hline
\end{tabular}




\begin{tabular}{|l|c|c|c|c|c|} 
& & & & & \\
\hline Tingkat Intelegensi(Antar Baris) & 1 & 262,399 & 262,399 & 52,048 & 4,03 \\
\hline Interaksi & 1 & 102,513 & 102,513 & 20,334 & 4,03 \\
\hline Galat & 52 & 262,159 & 5,042 & & \\
\hline
\end{tabular}

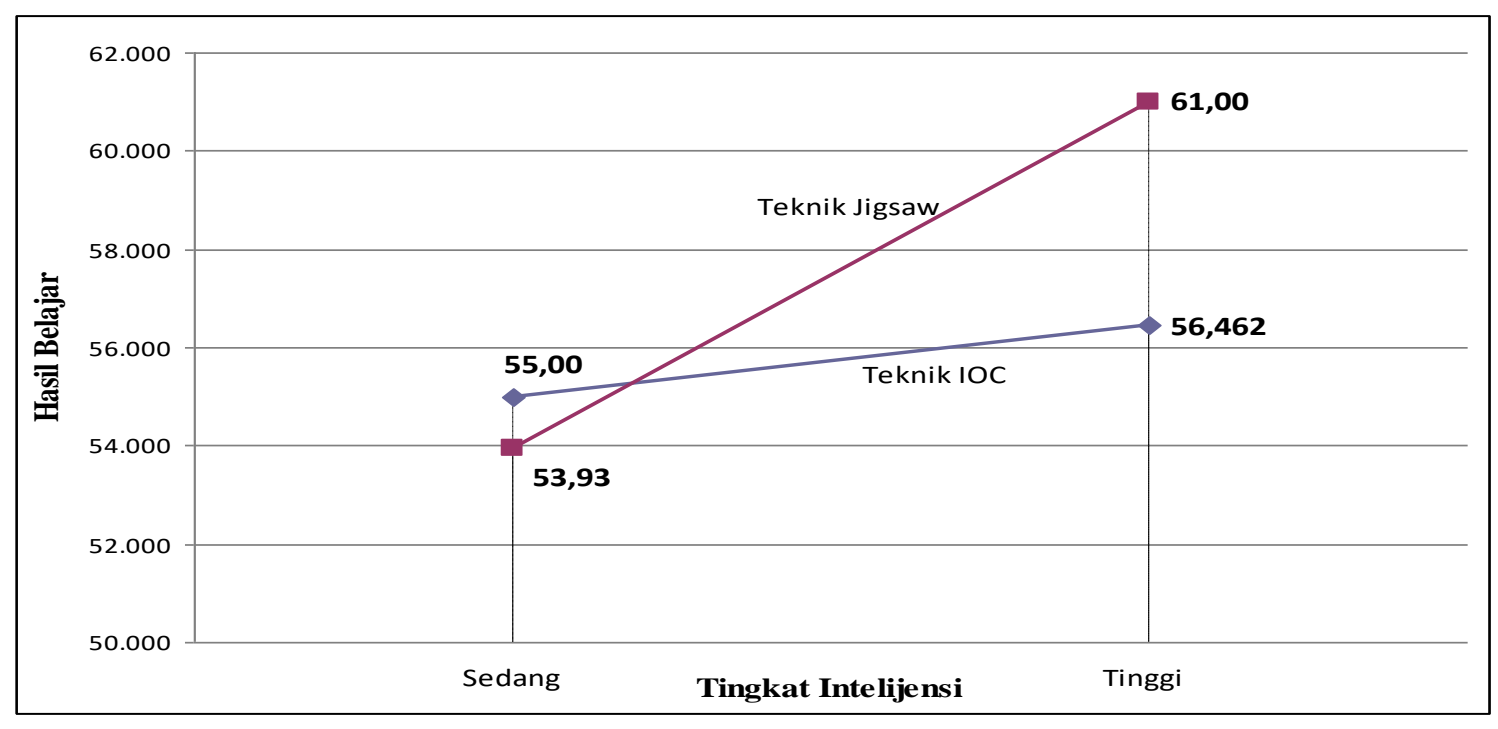

Gambar 6. Interaksi Antara Teknik pembelajaran dengan Tingkat IntelegensiTerhadap Hasil Belajar

Dari hasil pengujian diperoleh adanya interaksi antara teknik pembelajran dan Tingkat Intelegensiterhadap hasil belajar dan perlu diketahui variabel manakan yang memberikan pengaruh yang paling besar dalam peningkatan hasil belajar Biologi. Di antara berbagai perbandingan yang ada, untuk mengetahuinya perlu dilakukan uji lanjut dengan menggunakan uji Scheffe. Dari hasil perhitungan dapat dirangkum seperti pada tabel 7 berikut.

Tabel 7. Rangkuman Hasil Uji Lanjut Dengan Uji Scheffe

\begin{tabular}{|l|l|c|c|l|}
\hline \multicolumn{2}{|c|}{ Hipotesis Statistik } & $\mathbf{F}_{\text {hitung }}$ & $\mathbf{F}_{\text {tabel(3:52) }}(\boldsymbol{\alpha}=\mathbf{0 , 0 5})$ & \multicolumn{1}{|c|}{ Kriteria } \\
\hline $\mathrm{H}_{0}: \mu \mathrm{A}_{1} \mathrm{~B}_{1} \leq \mu \mathrm{A}_{1} \mathrm{~B}_{2}$ & $\mathrm{H}_{\mathrm{a}}: \mu \mathrm{A}_{1} \mathrm{~B}_{1}>\mu \mathrm{A}_{1} \mathrm{~B}_{2}$ & 69,431 & 2,79 & Signifikan \\
\hline $\mathrm{H}_{0}: \mu \mathrm{A}_{1} \mathrm{~B}_{1} \leq \mu \mathrm{A}_{2} \mathrm{~B}_{1}$ & $\mathrm{H}_{\mathrm{a}}: \mu \mathrm{A}_{1} \mathrm{~B}_{1}>\mu \mathrm{A}_{2} \mathrm{~B}_{1}$ & 27,540 & 2,79 & Signifikan \\
\hline $\mathrm{H}_{0}: \mu \mathrm{A}_{1} \mathrm{~B}_{1} \leq \mu \mathrm{A}_{2} \mathrm{~B}_{2}$ & $\mathrm{H}_{\mathrm{a}}: \mu \mathrm{A}_{1} \mathrm{~B}_{1}>\mu \mathrm{A}_{2} \mathrm{~B}_{2}$ & 51,708 & 2,79 & Signifikan \\
\hline $\mathrm{H}_{0}: \mu \mathrm{A}_{1} \mathrm{~B}_{2} \leq \mu \mathrm{A}_{2} \mathrm{~B}_{1}$ & $\mathrm{H}_{\mathrm{a}}: \mu \mathrm{A}_{1} \mathrm{~B}_{2}>\mu \mathrm{A}_{2} \mathrm{~B}_{1}$ & 8,578 & 2,79 & Signifikan \\
\hline $\mathrm{H}_{0}: \mu \mathrm{A}_{2} \mathrm{~B}_{1} \leq \mu \mathrm{A}_{2} \mathrm{~B}_{2}$ & $\mathrm{H}_{\mathrm{a}}: \mu \mathrm{A}_{2} \mathrm{~B}_{1}>\mu \mathrm{A}_{2} \mathrm{~B}_{2}$ & 2,951 & 2,79 & Signifikan \\
\hline $\mathrm{H}_{0}: \mu \mathrm{A}_{1} \mathrm{~B}_{2} \leq \mu \mathrm{A}_{2} \mathrm{~B}_{2}$ & $\mathrm{H}_{\mathrm{a}}: \mu \mathrm{A}_{1} \mathrm{~B}_{2}>\mu \mathrm{A}_{2} \mathrm{~B}_{2}$ & \multirow{2}{*}{1,649} & 2,79 & $\begin{array}{l}\text { Tidak } \\
\text { Signifikan }\end{array}$ \\
\hline
\end{tabular}

Secara umum intelegensi dapat dirumuskan sebagai berikut : (1) Kemampuan untuk berpikir abstrak. (2) Untuk menangkap hubungan-hubungan dan untuk belajar. (3). Kemampuan untuk menyesuaikan diri terhadap situasi-situasi baru. Sejauhmana seseorang dapat belajar dari pengalaman-pengalamannya akan menentukan penyesuaian dirinya. Ungkapan-ungkapan pikiran, cara berbicara, dan cara mengajukan pertanyaan, kemampuan memecahkan masalah, dan sebagainya mencerminkan kecerdasan.

Hasil belajar Biologi bagi siswa yang memiliki intelegensi tinggi lebih baik saat dilakukan pembelajaran dengan teknik jigsaw. Hal ini dikarenakan pada teknik jigsaw setiap anggota kelompok harus dapat bertanggung jawab dengan apa yang ditugaskan kepadanya 
kemudian memberikan informasi kepada kelompok lain. Dalam memberikan informasi, setiap orang wajib membaca pokok bahasan yang telah diberikan.

Teknik jigsaw juga menekankan rasa tanggung jawab siswa terhadap pembelajarannya sendiri dan juga pembelajaran orang lain. Siswa tidak hanya mempelajari materi yang diberikan, tetapi mereka juga harus siap memberikan dan mengajarkan materi tersebut pada anggota kelompoknya yang lain. Dengan demikian materi lebih mudah diserap oleh siswa karena penyampaian berasal dari temannya sendiri.

Sehingga siswa yang memilki intelegensi yang sedang akan sulit untuk menyesuaikan diri dengan teknik pembelajaran jigsaw. Hal ini disebabkan karena siswa yang memiliki intelegensi sedang membutuhkan waktu yang lebih banyak dan kesulitan yang lebih banyak pula saat mencoba mempelajari suatu materi secara mandiri. Kesulitan akan semakin bertambah saat siswa yang memiliki intelegensi rendah diminta untuk memberikan penjelasan terhadap materi kepada temannya.

Teknik inside-outside circle menekankan pada siswa untuk mengolah informasi dan meningkatkan keterampilan berkomunikasi antar siswa secara bergilir. Pada teknik ini siswa harus siap memberikan informasi yang akurat kepada siswa lain. Teknik ini sesuai untuk membantu siswa yang memiliki intelegensi sedang untuk dapat memahami materi. Diskusi yang dilakukan dengan siswa lain dapat mengurangi kesulitan yang dialami siswa dan dapat lebih mempersingkat waktu siswa yang memiliki intelegensi sedang dalam memahami materi yang didiskusikan.

Dari paparan di atas dapat disimpulkan bahwa siswa yang memiliki kecerdasan intelegensi tinggi lebih baik menggunakan teknik jigsaw dan siswa yang memiliki intelegensi rendah cocok menggunakan teknik inside-outside circle.

\section{Pembahasan}

Model pembelajaran kooperatif digunakan dalam kelas yang selalu diliputi kerjasama dalam menyelesaikan tugas. Dua perbedaan struktur tugas yang biasa digunakan adalah spesialisasi tugas dan kelompok belajar. Dalam spesialisasi tugas, beberapa anggota kelompok memberikan respon untuk bagian yang unik pada setiap aktifitas. Dalam kelompok belajar, semua anggota kelompok berkerjasama dan tidak memiliki respons yang terpisah (Ghaith, 2003).

Berdasarkan hasil penelitian yang dilakukan, dapat dilihat bahwa terdapat perbedaan hasil belajar Biologi antara siswa yang diajar dengan menggunakan Teknik Jigsaw dengan siswa yang diajar dengan menggunakan Teknik IOC. Nilai rata-rata hasil belajar siswa yang diajar dengan menggunakan Teknik Jigsaw lebih tinggi dengan nilai ratarata hasil belajar siswa yang diajar dengan menggunakan Teknik IOC. Hasil penelitian ini membuktikan bahwa hasil pembelajaran dengan menggunakan Teknik Jigsaw lebih sesuai untuk mata pelajaran biologi.

Hasil penelitian ini juga menunjukkan bahwa pembelajaran yang berpusat pada siswa lebih baik karena siswa lebih aktif untuk melakukan kegiatan pembelajaran dengan kreatifitas sendiri. Siswa diharapkan mampu menggunakan kemampuan berpikir untuk memecahkan berbagai soal-soal yang lebih rumit dan mampu membangun pola pikir dan pemahaman.

Hal ini disesuaikan dengan pendapat Elliot Aronson dalam The Jigsaw Classroom, yang menyatakan bahwa Jigsaw didesain untuk meningkatkan rasa tanggung jawab siswa secara mandiri juga dituntut saling ketergantungan yang positif (saling memberi tahu) terhadap teman sekelompoknya. Kunci tipe jigsaw ini adalah interdependensi setiap siswa terhadap anggota tim yang memberikan infomasi yang diperlukan dengan tujuan agar dapat mengerjakan tugas dengan baik. Berdasarkan paparan tersebut, dapat disimpulkan bahwa pembelajaran kooperatif teknik jigsaw adalah suatu metode pembelajaran yang didasarkan pada bentuk struktur multifungsi kelompok belajar yang dapat digunakan pada semua pokok bahasan dan semua tingkatan untuk mengembangkan keahlian dan keterampilan setiap anggota kelompok, teknik jigsaw terdiri dari dua bentuk diskusi yaitu diskusi kelompok ahli dan diskusi kelompok asal sehingga dalam metode pembelajaran ini tergantung pada dan belajar dari orang lain dan menciptakan saling ketergantungan bagi tiap anggota kelompok.

Teknik Jigsaw ini guru memperhatikan skema atau latar belakang pengalaman siswa dan membantu siswa mengaktifkan skemata ini agar bahan pelajaran menjadi lebih bermakna. Selain itu, siswa bekerja dengan siswa dalam suasana gotong royong dan mempunyai banyak kesempatan untuk 
mengolah informasi dan meningkatkan keterampilan komunikasi.

Berbeda dengan pembelajaran yang menggunakan Teknik IOC, siswa kurang aktif karena dalam pelaksanaannya proses pembelajaran yang dilaksanakan berpusat pada guru, dimana Teknik IOC tersebut hanya digunakan oleh guru untuk menjelaskan materi pembelajaran. Dengan demikian siswa cepat merasa bosan dan tidak terbangun ide-ide yang baru serta kreatifitas dalam menganalisis materi pelajaran biologi.

Teknik mengajar lingkaran besar dan lingkaran kecil (inside - outside - circle) dikembangkan oleh Spencer Kagan untuk memberikan kesempatan pada siswa agar saling berbagi informasi pada saat yang bersamaan. Pendekatan ini bisa digunakan dalam beberapa mata pelajaran, seperti ilmu pengetahuan alam, sosial, agama, matematika dan bahasa. Bahan pelajaran yang paling cocok digunakan dengan teknik ini adalah bahan yang membutuhkan pertukaran pikiran dan informasi antar siswa.

Berdasarkan hasil analisis uji hipotesis dan uji lanjut dengan menggunakan uji Scheffe menunjukkan bahwa hasil belajar Biologi siswa lebih tinggi dibandingkan dengan hasil belajar Biologi siswa yang diajar dengan menggunakan Teknik IOC.

Menurut Wahab dkk (2004), intelegensi adalah kemampuan yang dibawa sejak lahir yang memungkinkan sesorang berbuat sesuatu dengan cara tertentu, atau kemampuan yang bersifat umum tersebut meliputi tersebut meliputi berbagai jenis psikis seperti abstrak, berpikir mekanis, matematis, memahami, mengingat bahasa dan sebagainya.

Definisi intelegensi menurut Reber (1985) adalah kemampuan psikofisik untuk mereaksi rangsangan atau menyesuaikan diri dengan lingkungan dengan cara yang tepat. Sedangkan intelegensi menurut David Wechsler dalam Azwar, 2004 adalah kumpulan atau totalitas kemampuan seseorang untuk bertindak dengan tujuan tertentu, berfikir secara rasional serta menghadapi lingkungannya dengan efektif.

Siswa yang memiliki tingkat intelegensi tinggi lebih cepat mamahami materi pelajaran sehingga memberikan pengaruh yang berbeda terhadap hasil belajarnya. Siswa dengan tingkat intelegensi tinggi memperoleh hasil belajar yang lebih tinggi dari siswa yang memiliki tingkat intelegensi sedang.

Siswa dengan tingkat intelegensi tinggi lebih mudah memahami materi pelajaran dan lebih cepat meningkatkan pengetahuan, pemahaman dan keterampilan serta mampu melakukan pemecahan masalah pembelajaran sendiri. Kelompok siswa yang memiliki tingkat intelegensi tinggi, mampu beradaptasi dengan berbagai tuntutan materi pelajaran, mampu memunculkan ide-ide dan inisiatif pemecahan masalah atau soal-soal latihan, mempunyai sikap bertanggungjawab, memiliki rasa ingin tahu yang tinggi dan mudah dimotivasi.

Siswa dengan tingkat intelegensi sedang kurang mampu mengatasi persoalanpersoalan yang muncul dalam proses pembelajaran. Motivasi rendah, sehingga siswa tersebut hanya bersifat menunggu perintah dan masukan dari guru sebagai fasilitator, maupun meminta bantua dari teman atau siswa yang lain. Siswa tersebut tidak mampu menemukan alternatif pemecahan masalah dalam pengerjaan soal-soal latihan.

Berdasarkan teori Cattell dan Piaget bahwa terdapat pengaruh pengalaman, edukasi dan adaptasi dalam terbentuknya intelegensi seseorang. Intelegensi dapat diartikan juga sebagai kemampuan seseorang dalam menanggapi dan memahami peristiwa yang terjadi dalam kehidupannya. Baik dalam proses edukasi ataupun adaptasi yang terjadi selama manusia bersosialisasi dengan masyarakat dan lingkungan.

Kemampuan seseorang dalam memberikan tanggapan dan pemahaman selama proses edukasi dan adaptasi berbeda-beda. Sebagian orang dapat memberikan tanggapan dan pemahaman dalam waktu yang cenderung singkat, adapula yang membutuhkan waktu yang lebih lama untuk dapat memberikan tanggapan dan pemahaman dalam proses edukasi dan adaptasi yang sama. Kemampuan seseorang tersebut berhubungan dengan tingkat intelegensinya.

Siswa yang memiliki tingkat intelegensi tinggi dapat beradaptasi terhadap lingkungan belajar serta perubahan yang terjadi baik berupa materi maupun media dan lingkungan belajar lainnya. Sedangkan siswa yang memiliki tingkat IntelegensiSedang kurang kreatif, kurang mampu beradaptasi, serta kurang mampu mencari alternatif pemecahan masalah atau soal-soal pembelajaran.

Dari hasil penelitian yang dilakukan, diperoleh hasil bahwa siswa yang memiliki tingkat IntelegensiTinggi memperoleh hasil belajar yang tinggi dibandingkan dengan siswa yang memiliki tingkat IntelegensiSedang. 
Pembelajaran kooperatif (Cooperative Learning) merupakan suatu model pengajaran yang mengutamakan siswa untuk saling bekerjasama satu dengan lainnya untuk memahami dan mengerjakan segala tugas belajar mereka. Pendekatan kooperatif digunakan oleh para pendidik dalam pembelajaran di kelas dengan menciptakan situasi atau kondisi bagi kelompok untuk mencapai tujuan masing-masing anggota atau kelompok mencapai tujuan tergantung pada kerjasama yang kompak dan serasi dalam kelompok.

Beberapa unsur penting dalam Cooperative Learning meliputi kerjasama dalam menyelesaikan tugas, mendorong untuk bekerjasama yang terstruktur, tanggung jawab individu dan kelompok yang heterogen. Cooperative Learning digunakan dalam kelas yang selalu diliputi kerjasama dalam menyelesaikan tugas. Dua perbedaan struktur tugas yang biasa digunakan adalah spesialisasi tugas dan kelompok belajar. Dalam spesialisasi tugas, beberapa anggota kelompok memberikan respon untuk bagian yang unik pada setiap aktifitas. Dalam kelompok belajar, semua anggota kelompok berkerjasama dan tidak memiliki respons yang terpisah (Ghaith, 2003).

\section{Cooperative Learning diharapkan} dapat meningkatkan pemahaman siswa terhadap materi yang diajarkan, belajar untuk bekerjasama, menghargai pendapat orang lain dan tanggung jawab antara sesama siswa dan terhadap kelompoknya untuk memperoleh yang terbaik bagi kelompoknya dalam belajar dan menyelesaikan tugas.

Kegiatan bekerjasama dapat mengembangkan tingkat pemikiran yang tinggi, keterampilan komunikasi yang penting, meningkatkan minat, percaya diri, kesadaran bersosial dan sikap toleransi terhadap perbedaan individu. Beberapa kelompok siswa yang belajar dengan teknik-teknik yang telah dikembangkan atau diadaptasikan dan telah diteliti oleh Johns Hopkin dari universitas pusat untuk organisasi sosial sekolah menyatakan bahwa pada pembelajaran kelompok siswa memiliki dasar dimana ketika siswa belajar kelompok hampir sama seperti kelompok atletik. Dengan kedudukannya semua anggota melakukan yang terbaik bagi kelompoknya agar kelompokya berhasil. Ketiga teknik pembelajaran kooperatif yaitu STAD, TGT dan jigsaw telah secara ekstensif diteliti dan ditemukan dengan jelas telah meningkatkan hasil belajar (Swisher,2003).

Jigsaw adalah suatu struktur multifungsi struktur kerjasama belajar. Jigsaw dapat digunakan dalam beberapa hal untuk mencapai berbagai tujuan tetapi terutama digunakan untuk persentasi dan mendapatkan materi baru, struktur ini menciptakan saling ketergantungan.

Sedangkan, teknik inside-outside-circle memiliki keunggulan yaitu adanya struktur yang jelas yang memungkinkan siswa untuk berbagi dengan pasangan yang berbeda dengan singkat dan teratur. Selain itu siswa bekerja dengan sesama siswa dalam suasana gotong royong dan mempunyai banyak kesempatan untuk mengolah informasi dan meningkatkan keterampilan berkomunikasi.

Hasil penelitian memperlihatkan bahwa terdapat interaksi antara teknik pembelajaran dengan tingkat inteligensi terhadap hasil belajar Biologi. Hasil penelitian mengemukakan bahwa penggunaan teknik pembelajaran Jigsaw memberikan pengaruh yang lebih baik bila diterapkan pada kelompok siswa yang memiliki tingkat intelegensi tinggi dibanding bila diterapkan pada kelompok siswa yang memiliki tingkat intelegensi sedang. Hal ini dapat dilihat dari nilai hasil belajar kelompok siswa yang memiliki tingkat intelegensi tinggi, lebih tinggi dari nilai hasil belajar kelompok siswa yang memiliki tingkat intelegensi sedang.

Berdasarkan teori Piaget, setiap anak memiliki cara tersendiri dalam menginterpretasikan dan beradaptasi dengan lingkungannya. Menurutnya, setiap anak memiliki struktur kognitif yang disebut schemata yaitu sistem konsep yang ada dalam pikiran sebagai hasil pemahaman terhadap objek yang ada dalam lingkungannya. Pemahaman tentang objek tersebut berlangsung melalui proses asimilasi (menghubungkan objek dengan konsep yang sudah ada dalam pikiran) dan akomodasi (proses memanfaatkan konsepkonsep dalam pikiran untuk menafsirkan objek). Kedua proses tersebut jika berlangsung terus menerus akan membuat pengetahuan lama dan pengetahuan baru menjadi seimbang. Dengan cara seperti itu secara bertahap anak dapat membangun pengetahuan melalui interaksi dengan lingkungannya. Bila dalam proses asimilasi seseorang tidak dapat mengadakan adaptasi terhadap lingkungannya maka terjadilah ketidaksetimbangan (disequilibrium). Akibat ketidaksetimbangan itu 
maka tercapailah akomodasi dan struktur kognitif yang ada yang akan mengalami atau munculnya struktur yang baru.

Menurut teori Cattell terdapat pengaruh pengalaman, edukasi dan adaptasi dalam terbentuknya intelegensi seseorang. Intelegensi dapat diartikan juga sebagai kemampuan seseorang dalam menanggapi dan memahami peristiwa yang terjadi dalam kehidupannya. Baik dalam proses edukasi ataupun adaptasi yang terjadi selama manusia bersosialisasi dengan masyarakat dan lingkungan.

Hal ini sesuai dengan hasil penelitian yang diperoleh bahwa penggunaan teknik pembelajaran tidak selamanya berpengaruh terhadap hasil belajar siswa, hal tersebut dapat dilihat bahwa hasil belajar siswa dengan tingkat intelegensi sedang yang diajar dengan menggunakan teknik Jigsaw tidak jauh beda dengan hasil belajar siswa dengan tingkat intelegensi sedang yang diajar dengan menggunakan teknik IOC. Penggunaan teknik pembelajaran Jigsaw lebih cenderung terhadap peningkatan hasil belajar siswa yang memiliki tingkat intelegensi tinggi dibanding dengan siswa yang memiliki tingkat intelegensi sedang. Sebaliknya, siswa yang memiliki tingkat intelegensi sedang akan memperoleh hasil belajar yang lebih tinggi bila diajar dengan menggunakan teknik IOC.

\section{PENUTUP}

\section{Simpulan}

Berdasarkan hasil pengujian hipotesis seperti yang telah diuraikan, penelitian ini menyimpulkan bahwa: (1) Hasil belajar siswa biologi yang diajar dengan teknik jigsaw lebih tinggi dari pada hasil belajar siswa yang diajar dengan teknik IOC; (2) Hasil belajar biologi siswa yang memiliki tingkat intelijensi tinggi lebih tinggi dari hasil belajar siswa yang memiliki tingkat intelijensi sedang; dan (3) Terdapat interaksi antara penggunaan teknik dan tingkat intelijensi dalam mempengaruhi hasil belajar biologi. Hal ini berarti bahwa penggunaan teknik jigsaw terhadap siswa yang memiliki tingkat intelijensi tinggi, dapat memberikan hasil belajar yang lebih tinggi, dari pada penggunaan teknik IOC.

\section{Saran}

Guru Mata Pelajaran Biologi disarankan untuk menggunakan teknik jigsaw sebagai teknik belajar alternatif dalam pembelajaran biologi. Teknik jigsaw telah mampu meningkatkan hasil belajar biologi menjadi lebih baik.

Guru Mata Pelajaran Biologi sebaiknya mengenal dan memaksimalkan setiap tingkat intelijensi siswa serta menyesuaikannya dengan penggunaan teknik pembelajaran.

Bagi siswa yang memiliki tingkat intelijensi sedang lebih tepat bila diajar dengan menggunakan teknik IOC.

Penelitian ini masih sangat terbatas dari segi jumlah sampel dan waktu yang sudah dilakukan. Untuk menguatkan hasil penelitian ini disarankan kepada peneliti lanjut melakukan penelitian dengan jumlah sampel yang lebih besar dan waktu perlakuan yang lebih panjang.

\section{DAFTAR PUSTAKA}

Anonim., Cooperative Learning. Cooperative, http//Volcano.Und.Nodak,

Edu/vwdocs/msh/is/cl.html.(10 desember 2010)

Arikunto, (2002)., Dasar-dasar Evaluasi Pendidikan. Yogyakarta: Bumi Aksara.

Anastasi. A. (1997)., Tes Psikologi (Physicological Testing) Edisi Bahasa Indonesia Jilid 1. New York. Macmillan Publishing Co.INC.

Atkinson. R.Richard. A.,E (1999) Pengantar Psikologi Jilid 2 (terjemahan NurjannahAgus) Jakarta Erlangga.

Azwar, S. Pengantar psikologi intelegensi. Yogyakarta: Pustaka Pelajar.2004

Daroni. Pembelajaran Kooperatif Siswa di SLTP Melalui Model Jigsaw. Lembaran Ilmu Kependidikan Universitas Negeri Semarang. Tahun XXXI-No. 2: 225-241. 2002.

Ghaith, Ghazi. Fall 2003. Effects of Learning Together Model of Cooperative Learning on English as a Foreign Language Reading Achievement, Academic SelfEsteem, and Feelings of School Alienation. Bilingual Research Journal, 27:3.

Heru Basuki, A.M. (2005). Kreativitas, keberbakatan intelektual dan faktorfaktor pendukung dalam pengembangannya. Jakarta: Gunadarma.

Ibrahim, Nurdin. September.,(2001)., Hasil Belajar Fisika Siswa SLTP Terbuka Tanjung Sari Sumedang Jawa Barat. Jurnal Pendidikan dan Kebudayaan. Tahun ke 7- No. 031: 485-501.

Karuru, Predy. (2003). Penerapan Pendekatan Keterampilan Proses Dalam Seting Pembelajaran Kooperatif STAD Untuk 
Meningkatkan Kualitas Pembelajaran IPA Siswa SLTP. Tersedia:

http://depdiknas.go.id/jurnal/2003/45/Predy_kar uru.htm. (3 Januari 2006)

Kemp, J. E dan Dauton (1985). Planning and Producing Instruksional Media (fifth Edition). New York. Harper and Rows. Publisher

Lie, Anita., (2002) Cooperative Learning: Mempraktikan Cooperative Learning di Ruang-Ruang Kelas. Jakarta: PT Gramedia Widiasarana Indonesia.

Muslimin Ibrahim, Dkk. Pembelajaran Kooperatif. (Surabaya: Unesa Ò University Press, 2001)

Pannen, Paulina, dkk., (2001) Konstruktivisme Dalam Pembelajaran. Jakarta: UT,

Purwanto, M. Ngalim.Psikologi Pendidikan. Bandung: PT Remaja Rosdakarya, 2000.

Reber, A.S. The penguin dictionary of psychological. Harmondsworth Middlesex England: Penguin Books Ltd.1985

Sanjaya, Wina. (2005) Pembelajaran dalam Implementasi Kurikulum Berbasis Kompetensi. Jakarta: Kencana.
Slameto. (1995). Belajar dan faktorfaktor yang mempengaruhinya. Jakarta: PT Rineka Cipta. Suryabrata,

Suasti, Yurni. Desember 2003 . Upaya Peningkatan Kreativitas Siswa SMU Pembangunan UNP Melalui Modifikasi Cooperative Learning Model Jigsaw. Buletin Pembelajaran, Vol. 26-No. 04. Universitas Padang.

Susilana (2007). Media Pembelajaran. Bandung. CV Wacana Prima

Sumaji. Dkk.(2003) Pendidikan Sains yang Humanistis. Yogyakarta: Kanisius, 2003.

Suparno, A. Suhaenah. (2001) Membangun Kompetensi Belajar. Dirjen Pendidikan Tinggi Depdiknas.

Swisher, Karen. Januari 2003. Cooperative Learning and the Education of American Indian /Alaskan Native Students: A Review of the Literature and Suggestions For Implementation. Journal of American Indian Education,. Vol. 29-No. 2.

Syah, Muhibbin. (2004) Psikologi Pendidikan: dengan pendekatan baru. Bandung: PT Remaja Rosdakarya. 